\title{
Editorial
}

\section{Conscientious Brands Editorial}

Journal of Brand Management (2011) 18, 635-638. doi:10.1057/bm.2011.16

The idea behind conscientious brands emerged through discussions among likeminded brand thinkers and practitioners some 10 years ago. We were part of that original conversation and helped to form something that has become known as the Medinge Group, which among other activities, confers 'Brands with a Conscience' awards every year. Our original motivation was primarily to do with a concern as to the direction branding seemed to be heading in: abstracted, self-absorbed and narrow. Instead, we wanted to open branding up, to connect it with other areas and to humanize it. Underpinning this thinking was a stakeholder-based approach. With the increasing size and influence of organizations and their impact on more aspects of people's lives, we argued that their role had changed: 'companies have to recognize their accountability not only to shareholders, but to all audiences and to society as a whole' (Ind ed., 2003). This idea was not new in itself; R.E. Freeman (1984) has long argued that this stakeholder view is an ethical requirement of companies and that the interconnectedness of different stakeholders requires a balanced approach. In their 2007 book Freeman, Harrison and Wicks, write that competition is a second-order, emergent property and the primary aspect of corporations is cooperation. They suggest that the business organization should be a vehicle 'by which stakeholders are engaged in a joint and cooperative enterprise of creating value for each other' (Freeman et al, 2007).
This belief in a win-win ideal is not of course something that everyone agrees with. R. Martin (2010) describes the two stages of modern capitalism, from Berle and Means well-known 1932 work The Modern Corporation and Private Property, which signified the emergence of managerial capitalism to Jensen and Meckling's Theory of the Firm (1976) with its focus on shareholder capitalism (Martin, 2010). The emphasis on maximizing shareholder value has since become a shibboleth of modern management and argues quite explicitly for the preeminence of the shareholder. Martin's critique is that actually the focus on shareholders has not done anything for shareholder returns: 'there is no sign that shareholders benefited more when their interests were put first and foremost'. We might also add that shareholder capitalism has made organizations dysfunctional, in that it downplays the interdependence of audiences. As several studies have shown, involved and engaged employees are important contributors to customer satisfaction, which in turn leads to enhanced performance. Similarly, having a positive reputation helps a business to achieve its broader goals. Where we diverge from Martin is in his solution to the myopia of shareholder capitalism. His argument is that the new orientation should be customer capitalism and he cites two key examples of organizations who have exemplary longterm performance and live up to their rhetoric: Johnson \& Johnson and P\&G. They are interesting choices and they certainly give prominence in their corporate 
statements to consumers, but the important thing is that they stress the intertwining of stakeholders. Johnson \& Johnson's credo is both long-lived and well known and connects doctors, nurses, patients, parents, children, communities and stockholders. P\&G's principles state: 'We will provide branded products and services of superior quality and value that improve the lives of the world's consumers. As a result, consumers will reward us with leadership sales, profit and value creation, allowing our people, our shareholders and the communities in which we live and work to prosper'.

Having taken part in nominating and judging the 'Brands with a Conscience' awards since 2004 and reviewed a large number of organizations in the process, we have observed a divergence. There are those organizations that are still dominantly shareholder focused, but recognize a broader accountability. These businesses do address issues connected to corporate social responsibility (CSR), but they do not seem to integrate CSR into the fabric of what they do. It is still seen as a department or process that orbits far away from the corporate sun. By way of contrast, organizations, such as Patagonia, Pictet et $\mathrm{Cie}$ and Grameenphone, that are stakeholder focused are better at integrating CSR into their practices, because they see it as simply part of what they do everyday. Although this integration might be due to a philosophical stance, it is generally not altruism. It is connected to an understanding that businesses are not somehow separate from the world, but are very much part of it. For example, Danone's joint venture with Grameen's Muhammed Yunus to produce a low cost yoghurt called Shoktidoi, sold by village women in Bangladesh, is designed to yield only a small profit that is ploughed back into the venture. As a short-term investment it does not make so much sense, but combating poverty is important for the long-term growth of Danone as it reaches out into new markets. It also has the added benefit that the venture makes Danone more appealing as an employer. Similarly Hewlett-Packard (HP), which works with other companies, governments and NGOs to improve the health, education and infrastructure in developing markets, does so because long-term growth depends on new consumers. Simon Anholt writes of HP and others, that 'they (big companies) need consumers who are wealthy enough to buy their products, have enough free time to enjoy them, are educated enough to consume advertising messages and evaluate products and brands, and live in countries where there is the liberty to make money and spend it' (Anholt, 2003).

Key to all the cited examples is the prevalence of long-term thinking, which runs counter to the sometimes short-termist view of shareholders. Acting conscientiously means rejecting expediency for principle, temporary advantage for longterm gain. Grameenphone did not look such a good business prospect in the late 1990s in a country suffering from high levels of corruption, political uncertainty and poor infrastructure. But new distribution methods were established, low-cost pricing plans introduced and innovative services such as Healthline created. At present, Grameenphone has 21 million subscribers (2009) and is the most desired company to work for in Bangladesh. At Unilever, reducing environmental impacts while improving performance is core to the vision and it means taking a longerterm view and tackling short-termism head on. As part of that in 2009, CEO, Paul Polman stopped providing earnings guidance to investors, in an attempt to move the focus away from short-term returns. Seeing his mandate as more concerned with long-term success, he also railed against hedge funds, arguing, 'they are not people who are there in the long-term interests of the company'. Unilever has also been 
integrating its approach to sustainability across its brand portfolio, focusing on renewable resources (such that all the palm oil it sources will be from renewable supplies by 2015) and thinking about the implications not only of the act of purchase but also the use of product. Unilever has 400 brands that are used 2 billion times a day around the planet, with about 70 per cent of the greenhouse gas imprint occurring during use. Encouraging sensible and environmentally responsible use of products therefore can have a big impact.

\section{LET US FACE THE FUTURE}

The stakeholder-based approach is not without challenges. J. Frooman challenged the company centric bias of stakeholder theory, by arguing that relationships are seen from the organization's perspective (Frooman, 1999). In our ever more networked world, it seems clear that many of the conversations about brand take place with limited influence from the brand owner. The fact is that they always did, but suddenly in today's 'social media' world those previously private 'conversations' can now be heard and enjoined. It is no longer simply the case that the organization creates a set of linkages with others, but rather linkages are already there, changing and evolving all the time, some of which never touch the organization itself. Also, the ideal of all stakeholders working to create value for each other is often subverted by unequal pressure and resources that allows one stakeholder group to dominate the others. However, in spite of these difficulties, we also see a number of changes that will make conscientious brand behaviour ever more important. First in the wake of the Copenhagen climate summit (2009), it has become clear that governments are unable or unwilling to tackle some of the key issues facing the world environmentally. Into the breach have stepped corporate entities. We argued in Beyond Branding in
2003 that 'as businesses grow in power, so does their accountability. They acquire larger roles that put them at the centre of our social worlds. They can use this power for good by promoting essential freedoms ... or for control'. It seems clear that companies such as Unilever with its explicit environmentalist stance and Nike with its GreenXchange, which promotes the sharing and adoption of technologies that can meet sustainability challenges, have taken up the cause and are using their corporate power to effect change. Second, the increasing visibility of organizations brought about primarily by the internet has created an arena in which corporate actions are more easily scrutinized and discussed. Some brand owners see this as a distraction or a danger, but many others are embracing transparency and accepting the opportunity to get closer to their stakeholders. They want to be part of a dialogue, rather than passive recipients of comment and criticism. Third, there is a growing coincidence of interest. In many developed markets, growth rates are slow and there is limited future opportunity. The potential is in BRIC countries and also increasingly in developing economies. There literacy, knowledge, infrastructure, health and equality are the important spurs to growth. Brand owners can help drive these engines of growth and well-being by embracing a wider role and taking initiative to act conscientiously for all stakeholders.

At the end of the day, basic anthropology leads us to that truism which says that human behaviour is a constant, based on thousands of years of evolution, regardless of how anybody tries to analyse, interpret or package that behaviour. 'Humanity Based Strategy' (I. Ryder, 2004) is a very simple way of looking at the world and has just three basic precepts:

1. People are People First: everyone's first reaction to a situation is the human one 
and nothing you may try to plan for can override that, but if you understand it then you can make it work for yourself and others.

2. Manage the Reality Gap: there is always a difference between perception and reality. Understand that gap and manage it or someone else will do it for you.

3. Create 'Trust' and 'Relevance': probably two of the most important words in anybody's world. Without trust all is lost and unless something has relevance to an individual it will always be treated as 'noise'.

Understanding these basics and making them work is all part of building and managing conscientious brands. If organizations choose to follow this approach we would see an increase in brands truly acting for the real benefit of the world, as well as themselves and their stakeholders.

\section{REFERENCES}

Anholt, S. (2003) Brand New Justice: The Upside of Global Branding. Oxford: Butterworth-Heinemann, p. 160.

Freeman, R.E. (1984) Strategic Management: A Stakeholder Approach. Boston, MA: Pitman.

Freeman, R.E., Harrison, J.S. and Wicks, A.C. (2007) Managing for Stakeholders: Survival, Reputation and Success. New Haven, CT: Yale University Press, p. 6.

Frooman, J. (1999) Stakeholder influence strategies. Academy of Management Review 24(2): 191-205.

Ind, N. (ed.) (2003) Beyond Branding: How the New Values of Transparency and Integrity are Changing the World of Brands. London: Kogan Page.

Martin, R. (2010) The Age of customer capitalism. Harvard Business Review 88(1/2): 58-65.

Ryder, I. (2004) Anthropology and the brand. Journal of Brand Management 11(5): 346-356.

Nicholas Ind Editorial Board, Oslo School of Management Norway E-mail: Nicholas.Ind@mh.no

Ian Ryder Editorial Board, British Computer Society UK 